JUHÁSZ PÉTER

\title{
A súlyozott átlagos tőkeköltség alkalmazásának kihívásai
}

A súlyozott átlagos tőkeköltség (weighted average cost of capital, WACC) rendkívül gyakran jelenik meg elvárt hozamként projektek, üzletágak és cégek cash flow alapú értékelésekor. A tapasztalatok azonban azt mutatják, hogy míg a felhasználók a szïkséges pénzáramlás meghatározásának elveiben legtöbbször szigorúan követik az elméleti módszertan elöírásait, a tőkeköltség képletét gyakran nem igazítják az adott értékelési helyzethez. Pedig a súlyozott átlagos tőkeköltség tankönyvekben is gyakran egyedüli változatként felbukkanó, közismert formulája csupán a képlet egy speciális este, így annak nem kellően körültekintő alkalmazása inkonzisztens számításokhoz vezethet. E tanulmány levezeti a súlyozott átlagos tőkeköltség képletének közismert változatát, majd bemutatja annak tranzakciós költségeket és adópajzshatásokat figyelembe vevő új, általánosított változatát, illetve felhívja a figyelmet több, a súlyozott átlagos tőkeköltség becslése során felmerülő kihívásra is. Journal of Economic Literature (JEL) kód: G12, G30, G31, G32, H20, H25.

\section{Bevezetés}

A pénzáramlás-alapú (Discounted Cash Flow, DCF) értékelés lényege, hogy kiszámítjuk az értékelendő termék, projekt vagy vállalat jövőbeli pénzáramlásainak összesített jelenértékét, az úgynevezett belső (intrinsic) értékét. Ehhez előre kell jeleznünk az adott pénzügyi eszköz jövőbeli cash flow-ját, amit diszkontálnunk kell a kockázatosságának megfelelő nagyságú és a kifizetések időzítéséhez és pénzneméhez igazodó elvárt hozammal, azaz hozamelvárásunkat egy adott pénzáramlás jellemzőihez igazítjuk (cash flow matching) (Koller és szerzőtársai [2010] 6. fejezet). [Ez az eljárás nem egyezik meg azzal az azonos nevü kockázatkezelési eszközzel, amely során egy pénzáramlási kockázatot (leggyakrabban devizakockázatot) úgy semlegesítünk, hogy a beáramlással megegyező (azonos devizájú) pénzkiáramlást igyekszünk létrehozni.]

Juhász Péter, Budapesti Corvinus Egyetem Befektetések és Vállalati Pénzügy Tanszék (e-mail: peter. juhasz@uni-corvinus.hu).

A kézirat első változata 2019. február 24-én érkezett szerkesztőségünkbe.

DOI: http://dx.doi.org/10.18414/KSZ.2019.7-8.805 
A napi gyakorlatban és a szakirodalomban számos pénzáramlás-alapú értékelési megközelítést találunk, azonban csupán maroknyit mondhatunk tudományos értelemben is konzisztensnek és megalapozottnak. Racionális elvárás ugyanis, hogy egyazon vállalatra készült, azonos pénzügyi tervre (bemenő adatokra) épülő számítási eljárások pontosan azonos eredményre vezessenek. Erre csak akkor van lehetőség, ha a különböző pénzáramlásokat kockázatuk alapján tudatosan szétválasztjuk, hogy azokhoz megfelelö tőkeköltséget rendelhessünk (Easton-Sommers [2017]). Az egymással konzisztens pénzáramlás-alapú módszereket az 1. táblázat mutatja. (Az eredmények egyezését többek között Dempsey [2013] bizonyítja.)

\section{1. táblázat}

A leggyakoribb pénzáramlás-alapú eljárások

\begin{tabular}{|c|c|c|}
\hline Modell & Tőkeköltség & Megjegyzés \\
\hline $\begin{array}{l}\text { Vállalati szabad pénzáramlás } \\
\text { (Free Cash Flow to Firm, FCFF) }\end{array}$ & $W_{A C C^{*}}$ & $\begin{array}{l}\text { Projektek, üzletágak és ismert piaci } \\
\text { tőkeáttételü vállalatok értékeléséhez }\end{array}$ \\
\hline $\begin{array}{l}\text { Módosított jelenérték (Adjusted } \\
\text { Present Value, APV) FCFF + } \\
\text { finanszírozás eredményhatása } \\
\text { a finanszírozói kifizetések nélkül }\end{array}$ & $r_{A}$ & $\begin{array}{l}\text { Leválasztja a tőkeáttétel értékhatását } \\
\text { a működés értékéről }\end{array}$ \\
\hline $\begin{array}{l}\text { Tulajdonosi pénzáramlás } \\
\text { (Free Cash Flow to Equity, FCFE) }\end{array}$ & $r_{E}$ & $\begin{array}{l}\text { Közvetlenül a tulajdonosi pénzáramlásra } \\
\text { figyel, föként pénzügyi intézményekre } \\
\text { alkalmazható }\end{array}$ \\
\hline $\begin{array}{l}\text { Hozzáadott gazdasági érték } \\
\text { (Economic Value Added, EVA) }\end{array}$ & $W A C C^{*}$ & $\begin{array}{l}\text { Vállalati szemszögből mutatja } \\
\text { a többletérték realizálásának időpontját }\end{array}$ \\
\hline $\begin{array}{l}\text { Reziduális jövedelem } \\
\text { (Residual Income, RI) }\end{array}$ & $r_{E}$ & $\begin{array}{l}\text { Tulajdonosi szemszögből mutatja } \\
\text { a többletérték realizálásának időpontját }\end{array}$ \\
\hline
\end{tabular}

* WACC $=$ súlyozott átlagos tőkeköltség (weighted average cost of capital).

Forrás: Koller és szerzőtársai [2010] (104. o.) alapján, kiegészítve.

A pénzáramlás-alapú értékeléshez rendszerint éppen azért nem felelnek meg a különféle számviteli rendszerek által készített cash flow kimutatások, mert azok főcsoportjaiban általában keverednek a különféle kockázatú pénzáramlások. A magyar számviteli törvény szerinti cash flow kimutatásban például a sokszor tévesen müködésinek tekintett, úgynevezett szokásos pénzáramlás kategóriában többek között az operatív hatások és az elvileg finanszírozási tételnek számító kamatkiadások vannak összeadva.

Az értékeléshez szükséges üzleti cash flow kimutatás nemcsak tagolásában, de céljában is eltér a számviteli rendszerben létrejövő kimutatásoktól. E kimutatások ugyanis nem csak a müködés, a befektetés és a finanszírozás hatásait különítik el, de céljuk sem a pénzeszközök változásának bemutatása, hanem sokkal inkább a vállalat müködéshez nem szükséges eszközállományában bekövetkező módosulás levezetése.

Az értékeléshez használt pénzáramlások a jövőre vonatkoznak, és rendszerint olyan pénzügyi tervekre épülnek, amelyek nem számolnak az alaptevékenységhez nem szükséges eszközökkel. Miután a biztonságos müködéshez (a likviditás megőrzéséhez) szükséges pénzmennyiség változását a müködési cash flow-nak tartalmaznia 
kell, az üzleti pénzáramlás kimutatásainak utolsó sora, vagyis végeredménye nulla. Az üzleti pénzáramlás elvi sémáját a 2. táblázat mutatja.

2. táblázat

Az üzleti cash flow kimutatás tipikus szerkezete

Tétel Művelet $\quad$ Megjegyzés

Müködési eredmény (EBIT)

Az eredménykimutatás kizárólag a müködéshez kapcsolódó tételek egyenlege

EBIT $\times$ effektív társaságiadó-kulcs

- $\quad$ Az EBIT-re jutó elvi adó

Adózott működési eredmény (NOPLAT)

$=$

Értékcsökkenés

Nettó működő tőke változása

\section{Müködési cash flow}

Értékcsökkenés

Befektetett eszközök változása

Befektetések eredményhatása

$+$

- A mérleg müködéshez kapcsolódó sorainak változása

$=$

- Pótló beruházások

- Bővítő beruházások

$+\quad$ Az eredménykimutatás

befektetésekhez köthető tételei

A befektetési eredmény adóhatása

- Effektív adókulccsal számítva

II. Befektetési cash flow

$=$

I. + II. VÁllalATI SZABAD PÉNZÁRAMLÁs (FCFF)

Nem tulajdonosi finanszírozás

eredményhatása

A nem tulajdonosi finanszírozás (társasági) adóhatása

Nem tulajdonosi finanszírozás

állományváltozása

TULAJDONOSI SZABAD PÉNZÁRAMLÁs (FCFE)

Tulajdonosi finanszírozás eredményhatása

Tulajdonosi finanszírozás (társasági) adóhatása

Tulajdonosi finanszírozás változása
$+$

Az eredménykimutatás idegentőkefinanszírozáshoz kapcsolható tételeinek egyenlege (jellemzően negatív)

+ Általánosan elterjedt rövid neve adópajzs (A negatív eredmény adóhatása pozitív, mert csökkenti az adóalapot)

+ Finanszírozási célú kamatköteles adósság

$+\quad$ Jellemzően negatív

$+\quad$ A legtöbbször nulla

+ A mérleg tulajdonosi finanszírozáshoz köthető tételeinek változása (tőkeemelés, tőkeleszállítás)

Működéshez nem szükséges vállalati vagyon $\quad=$ Pénzügyi tervre épülő cash flow-nál változása nulla

NOPLAT (Net operating profit less adjusted taxes): adózás utáni működési eredmény. Számításához az EBIT-ből kell levonni az arra jutó adót. EBIT (Earnings Before Interests and Taxes): a vállalat kamatok és adózás előtti (müködési) eredménye.

Forrás: Koller és szerzőtársai [2010] (138. o.) alapján, kiegészítve. 
A cash flow egyeztetés (cash flow matching) arra épít, hogy az üzleti pénzáramlás kimutatása szétválasztja a vállalat által termelt szabad pénzáramlást tulajdonosi és hitelezői pénzáramlásra, s elkülöníti ezek adóhatását is. Így az egyes finanszírozók pénzáramlását a kockázatuknak megfelelő elvárt hozammal diszkontálhatjuk, hogy megkapjuk az adott tőkebiztosítói kör befektetésének értékét. Ez a lényege a tulajdonosi pénzáramlás (FCFE) módszerének, illetve például a kötvények pénzáramlásalapú értékelésének. E tanulmányban az idegentőke-finanszírozás (továbbiakban hitelek) pénzáramlás-alapú, azaz belső értékét a továbbiakban $D$-vel, a tulajdonosi tőkéét pedig $E$-vel jelöljük. Ezek összege adja egy adott időpontban $(t)$ a teljes egység (projekt, üzletág, cég) - a továbbiakban vállalat - értékét $(V)$.

$V_{t}=D_{t}+E_{t}$.

A vállalat tulajdonában lévő projektek összesített jelenértékét a továbbiakban $A$ (Assets) jelöli. Adók és tranzakciós költségek nélküli világban $V=A$.

Az elvárt hozamok meghatározásánál arra is figyelni kell, hogy azokat spot vagy (jellemzően egy évre szóló) forward hozamként értelmezzük-e. Több elemzés igazolta, hogy ezek azonos eredményre vezetnek, és matematikailag sem térnek el egymástól (Adamczyk-Zbroszczyk [2017b]).

Ugyanakkor spot hozamokra nemcsak sokkal összetettebb képleteket kapunk, de azok gyakorlati alkalmazása is roppant nehézkes, mivel a hozambecslésekhez szükséges tényezők (társaságiadó-kulcs, tőkeáttétel, gazdasági növekedés) előrejelzése jellemzően csak egy-egy adott hosszúságú időszakra (évre) elérhető, nem pedig változó hosszúságú időszakok átlagára. (Az egyetlen kivétel talán a kockázatmentes hozam, mivel a spot hozamgörbét gyakrabban szokták közzétenni, mint a forward hozamokat.) Block [2011] 225 Fortune 1000 indexbe tartozó cég kérdőíves vizsgálata alapján rámutat: a társaságoknak nincsen megcélzott stabil $D / V$ aránya, ezért évenként eltérő WACC használatára van szükség. Éppen ezért a továbbiakban a hozamokat egyéves forward hozamként értelmezzük.

Az 1. táblázatnak megfelelően lehetőség nyílik arra is, hogy a vállalat egészének pénzáramlását diszkontáljuk. Mivel az FCFF meghatározásánál az üzleti cash flow leválasztja a finanszírozási hatásokat, annak semmilyen befolyása sem lehet a vállalati pénzáramlásra. Márpedig a vállalat finanszírozási tevékenysége legalább két módon hatást gyakorolhat a cég értékére: 1 . befolyásolhatja a társaságiadó-alapot s így az adófizetés mértékét, 2 . hatást gyakorolhat a vállalkozás csődvalószínüségére is. Míg a vállalati szabad pénzáramlás $(F C F F)$ módszerénél ezek a hatások egy módosított tőkeköltségben, a súlyozott átlagos tőkeköltségben jelennek meg, addig a módosított jelenérték $(A P V)$ módszerénél a hatásokat várható pénzáramokkal ragadjuk meg, majd ezek jelenértékét adjuk az FCFF valós tőkeköltséggel diszkontált értékéhez. E tanulmány a továbbiakban a finanszírozás adóhatására és annak súlyozott átlagos tőkeköltségben való megjelenésére koncentrál.

Az FCFF-módszertan mindennapi jelentőségét jól mutatja, hogy az AdamczykZbroszczyk [2017a] által megvizsgált 224 lengyel részvényelemzés 84,7 százaléka e megközelítést használta. Csakhogy a kivitelezés sokszor hagy kívánnivalót maga után. Ezeknek az elemzéseknek ugyanis csupán 68 százaléka alkalmazott időszakonként 
eltérő átlagos tőkeköltséget, s az FCFF-et használók 86,6 százaléka semmiféle részletet sem közölt WACC-becslésének menetéröl. Így korántsem lehetünk biztosak abban, hogy a tőzsdei elemzők által elvégzett becslések teljesen helyesek.

Eközben gyakori, hogy az optimális tökeáttételi szintet éppen a WACC minimumaként határozzák meg (például Brusov és szerzötársai [2011]), azonban ha a képletet leegyszerüsítve, irreális (és sokszor implicit) feltevésekkel alkalmazzuk, akkor annak segítségével aligha határozható meg pontosan a legjobb finanszírozási mód.

\section{Tökéletes piacok}

Kiindulási alapként hasznos egy tökéletes piacból kiindulni, amelyben nincsenek társasági adók és tranzakciós költségek. Ha a teljes vállalat belső értékét a hitelek és a saját tőke együttes pénzáramlásából kiindulva akarjuk meghatározni, szükségünk van a két tőkeforma elvárt hozamainak valamilyen súlyozott átlagára is.

Ehhez Miller és Modigliani második tételét hívhatjuk segítségül (Miller-Modigliani [1961]), amely alapján a vállalati projektek $(A)$ átlagos elvárt hozama, az operatív tőkeköltség $\left(r_{A}\right)$ megegyezik a saját tőke $\left(r_{E}\right)$ és a hitelek $\left(r_{D}\right)$ elvárt hozamának piaci értékekkel súlyozott átlagával. A továbbiakban arra építünk, hogy ez az egyenlöség minden világállapotban fennáll.

$r_{A}=\frac{D}{V} r_{D}+\frac{E}{V} r_{E}$.

Ekkor a projektek szabad pénzáramlása megegyezik az FCFF-fel, tehát a WACC egybeesik az $r_{A}$-val, amely kizárólag a projektek kockázatától függ, és más, hasonló tevékenységü cégek adataiból jól becsülhető (1. ábra). Az egyszerüség kedvéért a továbbiakban egyetlen sajáttőke-fajtát és egyetlen hitelfajtát feltételezünk.

1. ábra

A vállalati mérleg piaci értékekkel tökéletes piacok mellett

\begin{tabular}{|c|c|c|c|c|c|}
\hline & Eszköz & & Forrás & & \\
\hline & 1. projekt & $r_{1}$ & Saját tőke $(E)$ & $r_{E}$ & FCFE \\
\hline$F F$ & $\vdots$ & $\vdots$ & & & \\
\hline & $N$-edik projekt & $r_{N}$ & Hitelek $(D)$ & $r_{D}$ & FCFD \\
\hline zzes, & $A=V$ & & & $r_{A}$ & \\
\hline
\end{tabular}

Az egyszerűség kedvéért a továbbiakban egyetlen sajáttőke-fajtát és egyetlen hitelfajtát feltételezünk.

$W A C C=r_{A}=\frac{D}{V} r_{D}+\frac{E}{V} r_{E}$.

Érdemes azonban tételesen végigvennünk az egyes ismeretlenek becslési kihívásait. A $D$ és az $E$ a hitelek és a saját tőke adott időszak kezdetén érvényes piaci értékét 
jelentik a mérlegben megszokott számviteli záróértékkel szemben. Az eredeti MillerModigliani-féle feltevések alapján az $r_{D}$ és az $r_{E}$ az ezekre a piaci értékekre elvárt egyéves forward hozamot fedik. Ez az értelmezés ragadt meg a leginkább a ma használatos egyetemi tananyagokban és a szakmai közéletben is. Sajnos azonban sokszor találkozunk a hozamok becslésénél azzal a hibával, hogy az egyes $r$-eket az elörejelzési horizontra vonatkozó átlaggal igyekeznek helyettesíteni, ami a spot hozamnál lehetne tényleg hasznos és helyes megoldás. A gond azonban az, hogy gyakran az így becsült hozamokat később forward értékként értelmezve hajtják végre a diszkontálást, időszakonként eltérő tőkeáttételi rátát alkalmazva.

A konzisztens értékelés folyamatának bemutatásához vegyünk egy egyszerủ számpéldát, amely illusztrálhatja a későbbiekben bevezetett módosítások hatásait is! Egy cég várhatóan a 3. táblázatban részletezett pénzügyi terv alapján müködik, s a harmadik évtől örökjáradék-szerü növekedést mutat, amelynek során a hitelek értéke együtt emelkedik a cégértékkel. ${ }^{1}$

\section{3. táblázat}

Illusztrációs pénzügyi terv

\begin{tabular}{|c|c|c|c|c|}
\hline & 1.év & 2. év & 3. év & 4. év és utána \\
\hline FCFF & 10 & 20 & 30 & 31 \\
\hline FCFF növekedése a 4. év után (százalék) & & & & 5 \\
\hline$r_{A}$ (egyéves forward) (százalék) & 10 & 11 & 12 & 13 \\
\hline$D / V$ év elején (százalék) & & & & 30 \\
\hline Szükséges befektetett tőke $[B V(E)+B V(D)]$ az év elején & 300 & 600 & 900 & \\
\hline Hitelek névértéke $[B V(D)]$ év elején ${ }^{a}$ & 100 & 100 & 100 & \\
\hline Hitelek kamata és elvárt hozama $\left[k_{D}=r_{D}\right]$ (százalék) & 3 & 4 & 5 & 6 \\
\hline
\end{tabular}

${ }^{a} B V$ (Book Value): könyv szerinti érték.

Tekintettel arra, hogy az FCFF megegyezik az adóhatások és tranzakciós költségek után a finanszírozók között szétosztható pénzáramlással, a cég mai értékét a következőképpen kaphatjuk meg.

$$
\begin{aligned}
& V_{3}=V_{4 . \text { év elején }}=\frac{31}{(13-5)}=387,50 . \\
& V_{2}=V_{3 . \text { év elején }}=\frac{387,5+30}{1,12}=372,77 . \\
& V_{1}=V_{2 . \text { év elején }}=\frac{372,77+20}{1,11}=353,84 . \\
& V_{0}=V_{1 . \text { év eljej́n }}=\frac{353,84+10}{1,10}=330,77 .
\end{aligned}
$$

${ }^{1}$ A cikk valamennyi számítását tartalmazó fájl elérhető a http://finance.uni-corvinus.hu/index. php?id=39786 oldalról. 
Ahhoz azonban, hogy elkülöníthessük a $D$ és az $E$ értékeit, ismernünk kell a hitelek elvárt hozamát is. Amennyiben az pontosan megegyezik a hitel kamatlábával, a hitelek névértéke megegyezik azok piaci értékével. [A cég hitelei a maradványidőszakban együtt nőnek majd a vállalat értékével, ezért a (8) képlet utolsó tagjában szereplő pénzáramlást az adott évi hitelfelvétellel még meg kellene emelni, az ott látható nem növekvő tagú örökjáradékot pedig növekvő tagú örökjáradékra kellene cserélni. Mivel azonban a maradványidőszakban mindig $r_{D}=k_{D}$ feltevéssel élünk, ez nem változtatná meg a kapott eredményt, csak a számítást tenné bonyolultabbá.]

$$
\begin{aligned}
& D_{0}=\frac{100 \times 3 \%}{1,03}+\frac{100 \times 4 \%}{1,03 \times 1,04}+\frac{100 \times 5 \%+(100-387,50 \times 30 \%)}{1,03 \times 1,04 \times 1,05}+ \\
& +\frac{387,50 \times 30 \% \times 6 \%}{1,03 \times 1,04 \times 1,05 \times(6 \%)}=100 .
\end{aligned}
$$

Innen az egyes időszakok végére már az (1) egyenlet segítségével meghatározható a saját tőke piaci értéke, így a (2) képletből meghatározható az $r_{E}$, és a (3) képlettel számolható a WACC is (4. táblázat).

\section{4. táblázat}

Piaci értékek adó- és tranzakciós hatások nélkül, $k_{D}=r_{D}$

\begin{tabular}{lrrrc}
\hline & 1. év & \multicolumn{1}{c}{ 2. év } & 3. év & 4. év és utána \\
\hline$V$ év elején & 330,77 & 353,84 & 372,77 & 387,50 \\
$D$ év elején & 100,00 & 100,00 & 100,00 & 116,25 \\
$E$ év elején & 230,77 & 253,84 & 272,77 & 271,25 \\
$D / V$ (százalék) & 30,23 & 28,26 & 26,83 & 30,00 \\
$r_{D}$ (százalék) & 3,00 & 4,00 & 5,00 & 6,00 \\
$r_{E}($ százalék) & 13,03 & 13,76 & 14,57 & 16,00 \\
$W A C C=r_{A}$ (százalék) & 10,00 & 11,00 & 12,00 & 13,00 \\
\hline
\end{tabular}

Más a helyzet azonban, ha a hitelek elvárt hozama és a kamata nem egyezik meg. Vegyük például az 5. táblázat szerinti elvárt hozamokat $\left(r_{D}\right)$. Mivel $r_{D}$ nem egyenlö $k_{D}$-vel, a hitelek piaci értéke sem egyezik meg a névértékkel (ami igen gyakran a könyv szerinti érték is). Ekkor a hitelek piaci értékét a (9) módon számíthatjuk ki.

$$
\begin{aligned}
& D_{0}=\frac{100 \times 3 \%}{1,04}+\frac{100 \times 4 \%}{1,04 \times 1,05}+\frac{100 \times 5 \%+(100-387,50 \times 30 \%)}{1,04 \times 1,05 \times 1,06}+ \\
& +\frac{387,50 \times 30 \% \times 6 \%}{1,04 \times 1,05 \times 1,06 \times(6 \%)}=97,26 .
\end{aligned}
$$

Ez az eset különösen azért releváns, mert a számviteli standardokban már egyre inkább követelmény a valós (piaci) érték bemutatása. Ilyenkor a könyv szerinti érték nem a hitelek névértéke, hanem az 5. táblázatban is látott év végi piaci érték lesz. 
5. táblázat

Piaci értékek adó- és tranzakciós hatások nélkül, $k_{D}<r_{D}$

\begin{tabular}{lrrrc}
\hline & \multicolumn{1}{c}{ 1. év } & \multicolumn{1}{c}{ 2. év } & 3. év & 4. év és utána \\
\hline$V$ év elején & 330,77 & 353,84 & 372,77 & 387,50 \\
$D$ év elején & 97,26 & 98,15 & 99,06 & 116,25 \\
$E$ év elején & 233,51 & 255,70 & 273,71 & 271,25 \\
$D / V$ (százalék) & 29,40 & 27,74 & 26,57 & 30,00 \\
$r_{D}$ (százalék) & 4,00 & 5,00 & 6,00 & 6,00 \\
$r_{E}$ (százalék) & 12,50 & 13,30 & 14,17 & 16,00 \\
$W A C C=r_{A}$ (százalék) & 10,00 & 11,00 & 12,00 & 13,00 \\
\hline
\end{tabular}

\section{Tranzakciós költségek beépítése}

Ugyanakkor igen gyakran előfordul, hogy a különféle finanszírozási források használata a kamat- vagy osztalékfizetésen felül valamilyen járulékos vagy tranzakciós költséggel is jár. Hitelfelvételhez számlát kell fenntartani az adott banknál, s szükség lehet például hitelbírálati díj fizetésére is. Az aktuális tulajdonosok ugyanakkor elvárhatják bizonyos speciális beszámolók elkészítését, könyvvizsgáló alkalmazását akkor is, ha az törvényileg nem kötelező, vagy ragaszkodhatnak a részvények tőzsdei jegyzéséhez (esetleg annak elkerüléséhez).

Amikor a devizában denominált hiteleken vagy a tulajdonos érdekkörében folyósított kölcsönökön árfolyamnyereséget vagy árfolyamveszteséget érünk el, az a mi cégünk eredményét befolyásolja ugyan, de nem mindig tekinthető a másik fél hozamának. Ha a finanszírozó idegen devizában vezeti könyveit, nála a nyereség vagy veszteség ellenlába egyáltalán nem jelenik meg. Ezeknek a tételeknek a finanszírozott cégnél érdemi eredményhatásai lehetnek, amelyek ugyanakkor nem jelenhetnek meg a tisztán müködési és beruházási hatásokat bemutató FCFF-ben. Így a hitelezőknek és a tulajdonosoknak jutó pénzáramlás összege nem azonos a cég finanszírozási pénzáramlásával, hiszen ez utóbbinak tartalmaznia kell a finanszírozási tranzakciós költségeket is, amelyeket a finanszírozók sokszor nem realizálhatnak. Illusztrációként a 6. táblázat szerint kiegészíthetjük a 3. táblázat kiindulási adatait, feltételezve, hogy a 4. év után ezek a költségek is együtt nőnek a céggel.

Ekkor a 2. ábra szerint módosul a cég vagyoni helyzete, ahol a TC a jövőbeli tranzakciós költségek jelenértékét jelenti. Mivel ennek értéke jellemzően negatív, kötelezettségként kell bemutatnunk. Vagyis $V<A$. A TC elvárt hozamaként azért célszerü az $r_{A}$ használata, mert így biztosítható, hogy a Miller-Modigliani-féle tétel egyenlete (2) az operatív tőkeköltségre továbbra is fennáll.

Ekkor a módosított jelenérték $(A P V)$ módszerét követve az FCFF-et csökkentenünk kell a várhatóan felmerülő veszteséggel, majd az így kapott együttes cash flow-t (vagy a két tagot külön-külön) diszkontáljuk az operatív tőkeköltséggel. Az 
6. táblázat

Feltevések a tranzakciós költségekről

\begin{tabular}{lcccc}
\hline & 1.év & 2.év & 3.év & $4 . e ́ v$ \\
\hline $\begin{array}{l}\text { Hitelekhez kapcsolódó, de a hitelezó által } \\
\text { hozamként nem realizált veszteség }\end{array}$ & 2 & 3 & 1 & 2 \\
$\begin{array}{l}\text { Sajáttőke-finanszírozáshoz kapcsolódó, de a } \\
\text { tulajdonos által hozamként nem realizált veszteség }\end{array}$ & 0 & 1 & 1 & 1 \\
\begin{tabular}{l} 
Tranzakciós költség cash flow (TC CF) összesen \\
\hline
\end{tabular} & 2 & 4 & 2 & 3 \\
\hline
\end{tabular}

2. ábra

A vállalati mérleg piaci értékekkel, tranzakciós költségekkel

\begin{tabular}{lcc|ll} 
& \multicolumn{1}{l}{ Eszköz } & \multicolumn{2}{l}{ Forrás } \\
\cline { 2 - 5 }$A r_{A}$ & 1. projekt & $r_{1}$ & Saját töke $(E)$ & $r_{E}$ \\
& $\vdots$ & $\vdots$ & Hitelek $(D)$ & $r_{D}$ \\
Összesen & $N$ & $r_{N}$ & $T C$ & $r_{A}$ \\
\cline { 2 - 5 } & $N$-edik projekt & $r_{V}$ & $r_{A}$
\end{tabular}

így meghatározott vállalati értéket azonban csak akkor kapjuk meg az FCFF-böl, ha a WACC eddig használt, $r_{A}$-val megegyező képletét a (10) képlet szerint módosítjuk.

WACC $_{t}=\frac{D_{t-1}}{V_{t-1}} r_{D_{t}}+\frac{E_{t-1}}{V_{t-1}} r_{E_{t}}+y_{V_{t}}$,

ahol

$y_{V_{t}}=\frac{T C C F_{t}}{V_{t-1}}$.

Természetesen úgy is eljáratunk, hogy a tranzakciós költség cash flow (TC CF) egyes elemeit jellegüknek megfelelően a saját tőke, illetve a hitelek piaci értékének arányában fejezzük ki, ha tudjuk, hogy azokkal arányosak. Például a hitelfelvétel tranzakciós költsége lehet a folyósítási díj egy adott évben, amely a hitelösszeg adott százaléka. Ez a (10) képlettel matematikailag ekvivalens, ha $y_{E}=y_{D}$, és néhány esetben könnyebben áttekinthetö képet ad. Ekkor az $A P V$-értékelés eredményéhez igazodó $W A C C$-képlet a következö:

$W A C C_{t}=\frac{D_{t-1}}{V_{t-1}}\left(r_{D_{t}}+y_{D_{t}}\right)+\frac{E_{t-1}}{V_{t-1}}\left(r_{E_{t}}+y_{E_{t}}\right)$,

ahol

$y_{D_{t}}=\frac{T C C F_{D_{t}}}{D_{t-1}}$

és

$y_{E_{t}}=\frac{T C C F_{E_{t}}}{E_{t-1}}$. 
Az APV megközelítés nagy előnye lehet, hogy a felmerülő tranzakciós költségeket pénzben összegszerüen kell elöre jeleznünk, nem pedig a valamelyik piaci érték $(V, D, E)$ arányában. Ez például a historikus adatok vagy a megkötött szerződések alapján jóval könnyebben megtehetö, míg az értékarányok $(y)$ helyes becsléséhez iterációra van szükség, hiszen a $W A C C$ becslésének célja az értékelés, amelynek végeredményét ( $V$-t, vagy az abból számolt $E$-t) fel kellene használnunk a tőkeköltség megbecsléséhez.

A (10) és (12) egyenlet helytállóságát a következőképpen láthatjuk be. A valóságban a hitelezők a hitelek változásához és a kamatfizetéshez kapcsolódó pénzáramlást realizálják, amelynek kockázatához az $r_{D}$ elvárt hozam tartozik, míg a tulajdonosok $r_{E}$ elvárt hozam mellett az FCFE-t kapják. E két cash flow összegét tehát a (4) egyenletnek megfelelő $r_{A}$ tőkeköltséggel kell diszkontálnunk. A finanszírozáshoz köthető tranzakciós költségek bevezetésével az FCFF éppen TC CF-fel haladja meg a hitelezők és a tulajdonosok összesített pénzáramlását.

Az FCFF-hez igazodó tőkeköltség képletének meghatározásához olyan fiktív világot kell elképzelnünk, amelyben a két finanszírozói csoport ugyan valóban ezt az összeget kapja meg, de további kifizetések miatt csak a valós világban megszokott hozam marad náluk. Ez lényegében azt jelenti, hogy a finanszírozás tranzakciós költsége a finanszírozókat terheli. (Ez a gondolatmenet hasonlít a derivatívák kockázatsemleges világban való árazásához.)

Ehhez arra lesz szükség, hogy a tulajdonosok $T C C F_{E}$, a hitelezők pedig $T C C F_{D}$ összeget veszítsenek el, például egy harmadik félnek való kifizetéssel. [A módosított jelenérték $(A P V)$ megközelítésnél e harmadik felet ugyanekkora összeggel nem a finanszírozók fizetik ki, hanem maga a vállalat.] Ekkor viszont mindkét fél jogosan várja el, hogy többletkiadásait fedezze a vállalattól kapott megemelt jövedelem. A többletelvárást a hitelezők a (13), a tulajdonosok a (14) képlet alapján határozhatják meg a befektetéseik aktuális piaci értékének arányában. Mivel mindkét esetben minden fél éppen azonos pénzáramláshoz jut ugyanakkora kockázat mellett, a képzelt világban az FCFF diszkontálásával kapott eredmény azonos értékre kell vezessen a valós világ $A P V$ módszerével (3. ábra).

3. ábra

A WACC korrekciója finanszírozási tranzakciós költségekkel

Valós világ

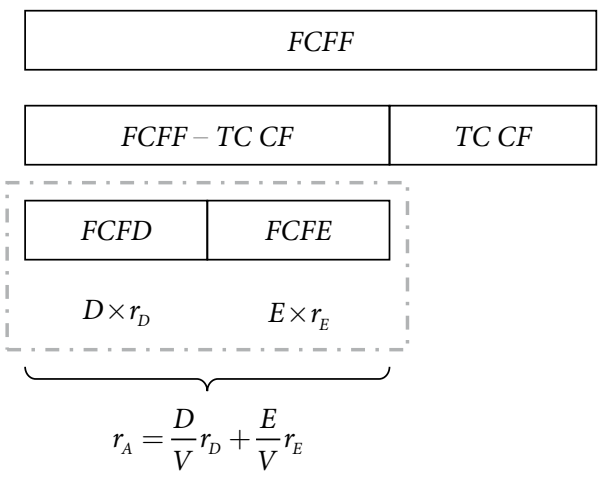

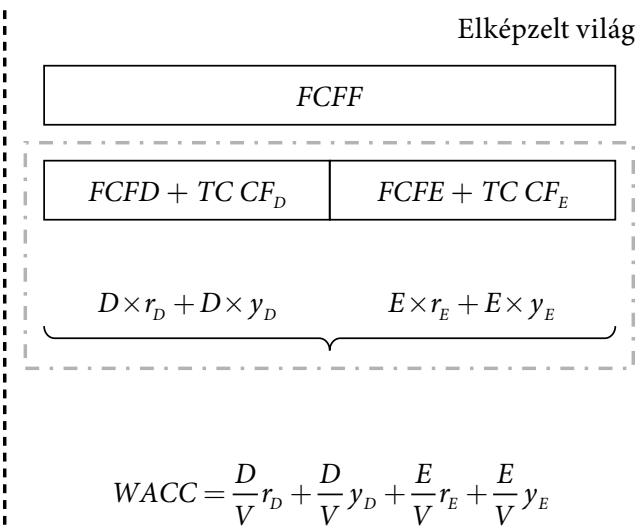


A kapcsolódó illusztrációs számításokat a 7. táblázat tartalmazza. Érdemes felfigyelni arra, hogy a tranzakciós költségek felmerülése a cégre kedvezőtlenül hat. Amennyiben ennek hatását a WACC-ben megjelenítjük, akkor a súlyozott átlagos tőkeköltség rendre meghaladja az adott évi operatív tőkeköltséget. Ez olyan helyzet, amelyet a szakirodalom csak elvétve tárgyal.

\section{7. táblázat}

Piaci értékek finanszírozási tranzakciós költségekkel, adóhatások nélkül, $k_{D}<r_{D}$

\begin{tabular}{lrrrr}
\hline & 1. év & 2.év & 3. év & 4 .év és utána \\
\hline$V$ TC-hatás nélkül & 330,77 & 353,84 & 372,77 & 387,50 \\
TC CF & 2,00 & 4,00 & 2,00 & 3,00 \\
TC év elején & 33,98 & 35,38 & 35,27 & 37,50 \\
TC/V TC-hatás nélkül & 10,27 & 10,00 & 9,46 & 9,68 \\
$V$ TC-hatással év elején & 296,79 & 318,47 & 337,50 & 350,00 \\
\hline$D$ év elején & 97,26 & 98,15 & 99,06 & 105,00 \\
E év elején & 199,53 & 220,32 & 238,44 & 245,00 \\
\hline D/V TC-hatással év elején (százalék) & 32,77 & 30,82 & 29,35 & 30,00 \\
E/V TC-hatással év elején (százalék) & 67,23 & 69,18 & 70,65 & 70,00 \\
$r_{D}$ (százalék) & 4,00 & 5,00 & 6,00 & 6,00 \\
$y_{D}$ (százalék) & 2,06 & 3,06 & 1,01 & 1,90 \\
$r_{E}$ (százalék) & 12,92 & 13,67 & 14,49 & 16,00 \\
$y_{E}$ (százalék) & 0,00 & 0,45 & 0,42 & 0,41 \\
WACC (százalék) & 10,67 & 12,26 & 12,59 & 13,86 \\
\hline
\end{tabular}

Érdemes megjegyezni, hogy a $T C C F$-et három részre is oszthatjuk, annak függvényében, hogy az egyes elemek inkább az $E$, a $D$ vagy a $V$ értékével mozognak együtt. Vegyük észre, hogy $y_{E}=y_{D}$ azt jelenti, hogy az adott $T C C F$ elem valójában $V$-vel arányos. Tehát ha $y_{E}=y_{D}$ igaz, akkor $y_{E}=y_{D}=y_{V}$ is igaz.

Természetesen a bemutatott képlet alkalmazása nem jelenti azt, hogy muszáj feltételeznünk, hogy a tranzakciós költségek együtt mozognak a $D, E$ vagy $V$ értékével. Csupán arról van szó, hogy ha nem ismerjük a költségek arányát egyik mennyiség piaci értékének arányában sem, akkor a WACC alkalmazását igénylö pénzáramlásos $(D C F)$ módszerek, így különösen a vállalati szabad pénzáramláson $(F C F F)$ alapuló megközelítés nem használható, vagy iterációt igényel. Helyette az összegszerü előrejelzést megkívánó módosított jelenérték ( $A P V)$ módszer kínálhat megoldást. 


\section{A társasági adó hatása}

Miller-Modigliani [1961] rámutat: ha van társaságiadó-hatása a finanszírozásnak, akkor a tőkeáttételes cég $\left(V_{L}\right)$ értéke a (14) képlet alapján bontható fel a tőkeáttétel nélküli cégérték $\left(V_{U}\right)$ és a generált adóhatás, azaz az adópajzshatás (Tax Shield, TS) összegére, vagyis a hatás additív (Vélez-Pareja-Burbano-Pérez [2006]).

$V_{L}=V_{U}+T S$.

A két értékalkotó tényező nagyságának meghatározása azonban az üzleti cash flow alapján közvetlenül nem lehetséges. Vegyük észre ugyanis, hogy a két finanszírozási forma számára rendelkezésre álló együttes pénzáramlást az üzleti cash flow nem mutatja be külön soron. Ahhoz, hogy ezt megkapjuk, az FCFF értékéhez a finanszírozások adóhatásait is hozzá kell számítanunk.

A finanszírozás adóhatásaként a leggyakrabban a kamatok adóalapból való levonhatóságát szokás említeni, amelyet úgy becsülnek, hogy a kamatfizetést és az adókulcsot $(t)$ összeszorozzák. Csakhogy ezt a számítási megközelítést érdemes pontosítani, ráadásul vannak helyzetek, amikor e megközelítés még a kamatok adóhatásának megragadására is elégtelen. Mi több, a finanszírozáshoz kapcsolódóan korántsem ez az egyetlen lehetséges adómegtakarítási hatás.

Elsőként az alkalmazott adókulcsot érdemes vizsgálni. Ez semmiképpen sem egyezik meg az adótörvényekben meghatározott nominális adókulccsal, hiszen azt az adóalap és nem az adózás előtti eredmény után kell megfizetni. A két mennyiség eltérését nem csupán a kötött jogszabályi előírásokkal dolgozó adószámvitel és a sokszor választási lehetőségeket felkínáló iránymutatásokat tartalmazó pénzügyi számvitel közti szemléletbeli különbség magyarázza, de a különféle adó- és adóalap-kedvezmények létezése is.

Éppen ezért szokás az adótörvényeket követve meghatározott ténylegesen fizetendő adó és az adózatlan eredmény hányadosaként adódó effektív adókulcs használata. Ez a mennyiség jól használható a napi gyakorlatban, ugyanakkor minden kapott adókedvezményt egyenletesen oszt el a különféle számviteli eredményt befolyásoló tételek között. Ha tehát kellően szofisztikált előrejelzést készítünk, és az adófizetési kötelezettséget pontosan igyekszünk elöre jelezni, hiába tartozik egy adott kedvezmény valamilyen konkrét müködési, befektetési vagy finanszírozási tételhez, a kiváltott adóhatás mégis minden cash flow részben meg fog jelenni. Ez azonban ellentétes az FCFF finanszírozási hatásoktól való mentességének elvével. E problémán a gyakorlatban az adókedvezmények előrejelzésének egyszerủ elhagyásával szoktak felülemelkedni a pénzügyi modellek készítői.

Ha fejlesztési célú projektekről döntünk, az elmélet szerint a marginális adókulcsot kell használnunk, hiszen az mutatja meg, hogy mekkora adóterhelés jut a következő egységnyi jövedelemre. Ennek meghatározása különösen a többféle társaságiadókulcsot is alkalmazó társaságiadó-rendszerekben lehet nehézkes.

Ráadásul korántsem biztos, hogy egy-egy konkrét eredménycsökkentő tétel valóban adókedvezményt okoz. Hiszen az adófizetés ténye a legtöbb adórendszerben a cég jövedelmezőségétöl függ. Veszteséges társaságok a legtöbbször nem fizetnek 
társasági adót, vagyis a kamatok okozta adómegtakarítás mértéke függ az FCFF részeként meghatározott üzemi szintü jövedelmezőségtől (Vélez-Pareja-Tham [2005]). Amikor tehát az FCFF finanszírozástól való elkülönítéséről van szó, az sokszor igen egyoldalú, hiszen a finanszírozásnak nem szabad hatnia az FCFF-re, de ez utóbbi befolyásolja a finanszírozási pénzáramlást. Ezt a feszültséget csak azzal lehetne feloldani, ha pontosan szétválasztanánk az adókedvezmények okozta hatásokat, viszont a felmerült többletköltségek és a kapott nagyobb pontosság összevetése alapján sokszor nem éri meg az erőfeszítést.

Qi és szerzőtársai [2012] is rámutat, hogy a korábbi próbálkozások az adópajzs realizálása körüli bizonytalanság megragadására olyan bonyolult képleteket tartalmaztak, amelyek a napi gyakorlatban használhatatlannak bizonyultak. Éppen ezért a szerzők azt javasolták, hogy a WACC-képletben szereplő adókulcsot valószínüségi változóként kellene meghatározni, ezzel lényegében egyetlen effektív adókulcs alkalmazása helyett minden időszakra inkább egyfajta várható érték számítását jelenti.

Tovább bonyolítja a helyzetet egyes adórendszerek sajátos szerkezete. Például a magyar rendszer elvárt minimális adója végeredményben oda vezet, hogy pozitív adófizetés mellett is lehetséges, hogy a kamatok nem kínálnak adópajzshatást. E sajátosság korrekt figyelembevétele az értékelési modellt szintén céltalanul bonyolulttá teheti.

A hitelekhez kapcsolódó kamatok miatti adócsökkenés (adópajzs) ráadásul speciális esetekben el is térhet a szokásosan számolttól. Gyakori hiba például a kamatfizetést a hitelek piaci értékének és elvárt hozamának szorzataként $\left(D \times r_{D}\right)$ számítani, mert ez kizárólag abban az esetben állja meg a helyét, ha a hitelek elvárt hozama és adószámvitelben elszámolható kamata azonos $\left(r_{D}=k_{D}\right)$, és a hitelek névértéke és piaci értéke is megegyezik.

Ez azonban nem csak az elöre rögzített kamatozású hiteleknél nem teljesül, de például sajátos adózási elöírások is eltéréshez vezethetnek. Például Magyarországon a kis- és középvállalkozások beruházásihitel-kamata utáni adókedvezmény lehetővé teszi a hitelkamat adóból való leírását. Ez azt jelenti, hogy az ilyen hitelek a szokásos adópajzson felül saját összegüknek megfelelő további adókedvezményt adnak. Vagyis a hitel tényleges adókedvezménye kamat $\times t$ helyett kamat $\times(1+t)$ módon lenne számítható. Azonban e többletadópajzs összességében nem haladhatja meg a nélküle számított társasági adó 70 százalékát. A gyakorlatban az effektív adókulcs alkalmazása e finomságok hatását elkeni, s a kapott adókedvezmények nagyságát egyenletesen szétosztja a különféle számviteli eredményt (nem adóalapot!) befolyásoló tételek kötött.

A helyzet azonban még ennél is összetettebb lehet. Láttuk ugyanis, hogy a finanszírozásnak lehetnek tranzakciós költségei is. E költségek jó része csökkenti a társasági adóalapot, de gyakran elöfordul, hogy azokat részben nem is a vállalat viseli. Például egyetlen magánszemély tulajdonában álló vállalkozás esetében a hitel megszerzéséhez szükség lehet arra, hogy a cégben egyébként nem dolgozó tulajdonos is részt vegyen a tárgyalásokon. A családi kézben lévő cégek esetében a piaci megállapodások megkötésekor szükség lehet a tulajdonosok megjelenésére is (ez egy multinacionális cég leányvállalatánál sokszor szükségtelen), akik az ehhez kötődő költségeiket nem tudják elszámolni a vállalaton belül. A tulajdonosi elvárt hozam tehát az ilyen 
költségek miatt lehet az egyébként megszokott $r_{E}$-nél magasabb, miközben adómegtakarítást nem generál.

Ha azonban a tulajdonos valamely családtagját érdemi munkavégzés nélkül is felteszi a vállalati bérlistára, esetleg magánkiadásait is a vállalattal fizetteti meg, akkor tulajdonképpen olyan tulajdonosi hozamkivételt valósít meg, amely adópajzsot generál, szemben a szokásos osztalékfizetéssel, amely nem befolyásolja az adóalapot, s így adópajzshatása sincsen.

Az adómegtakarítás pénzáramlásának diszkontálásához használandó helyes elvárt hozamról $\left(r_{T S}\right)$ ugyanakkor a szakirodalomban nincsen egyetértés. (A különféle felvetésekről többek között lásd Ansay [2009], DeMarzo [2005] és Kolari [2014].) Összefoglalásként ugyanakkor elmondhatjuk, hogy a javasolt ráták az $r_{D}$ és $r_{A}$ közötti mindkét oldalon zárt intervallumba esnek. ( $\mathrm{Az} r_{\mathrm{A}}$ két szélsőséges feltevés melletti meghatározásáról részletesen lásd Koller és szerzőtársai [2010] D függelékét.) Tekintettel arra, hogy a saját tőke kockázata magasabb, az elvárt hozamokra igaz, hogy $r_{E}>r_{D}$. Mivel $r_{E} \geq r_{A}, r_{A}$ sosem kisebb, mint $r_{D}$.

E tanulmány a továbbiakban az adópajzs diszkontálására az $r_{A}$-t alkalmazza. Ennek nem csak az az előnye, hogy így az adópajzs értékhatása minimális lesz (kisebb az esélye annak, hogy a cégértéket felülbecsüljük, ami például a számviteli kimutatásoknál kritikus), de számos képlet és számítás is egyszerüsödik. Így ugyanis biztosítható (ahogy azt a tranzakciós költségeknél is láttuk), hogy fennmaradjon az operatív tőkeköltség MillerModigliani-féle (2) képletének alkalmazhatósága. A bemutatott okfejtés bármely $r_{T S}$ mellett helytálló, ám a levezetés megértését lényegesen segíti ez a választás.

Mivel az adómegtakarítás a tisztán saját tőkéből finanszírozott céghez képest többletpénzáramlást biztosít a finanszírozók számára, a jövőbeli adópajzshatások (TS CF) jelenértékei (TS) az eszközoldalra kerülnek. A 4. ábra mutatja a piaci értékekkel felírt mérleg megfelelő kiegészítését.

4. ábra

A vállalati mérleg piaci értékekkel, tranzakciós költségekkel és adópajzzsal

\begin{tabular}{|c|c|c|c|c|}
\hline \multirow{5}{*}{$A r_{A}$} & Eszköz & \multicolumn{2}{|r|}{ Forrás } & \\
\hline & 1. projekt & $r_{1}$ & Saját töke $(E)$ & $r_{E}$ \\
\hline & & $\vdots$ & Hitelek $(D)$ & $r_{D}$ \\
\hline & $\mathrm{N}$-edik projekt & $r_{N}$ & & \\
\hline & $T S$ & $r_{A}$ & $T C$ & $r_{A}$ \\
\hline Összesen & $V$ & $r_{V}$ & & $r_{A}$ \\
\hline
\end{tabular}

Annak érdekében, hogy e feltételek között is levezethessük a WACC megfelelö képletét, ismét vissza kell térnünk a tranzakciós költségeknél látott fiktív világunkhoz (5. ábra). Ezúttal azonban nem csak a tranzakciós költségeket fizetheti vagy a vállalat, vagy a finanszírozók, de ugyanígy kaphatja az adókedvezményt a felek bármelyike. Ha viszont az adómegtakarítást a finanszírozók kapják az államtól, amely a cégtől a valós világhoz képest túlságosan sok adót szed be, hozamelvárásuk ennek megfelelően csökken. 
5. ábra

A WACC korrekciója finanszírozási tranzakciós költségekkel

Valós világ

\begin{tabular}{|l|l|}
\hline FCFF & TS CF \\
\hline
\end{tabular}

\begin{tabular}{|l|l|}
\hline FCFF - TS CF-TC CF & TC CF \\
\hline
\end{tabular}

FCFD + TS CF + TCCF

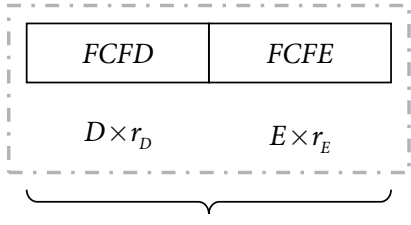

$$
r_{A}=\frac{D}{V} r_{D}+\frac{E}{V} r_{E}
$$

Elképzelt világ

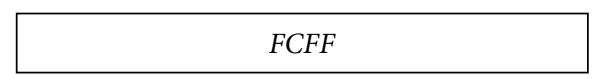

$D \times r_{D}-D \times i_{D}+D \times y_{D} \quad E \times r_{E}-E \times i_{E}+E \times y_{E}$

$\underbrace{}_{W A C C}=\frac{D}{V} r_{D}-\frac{D}{V} i_{D}+\frac{D}{V} y_{D}+\frac{E}{V} r_{E}-\frac{E}{V} i_{E}+\frac{E}{V} y_{E}$

Ekkor a saját tőke és a hitel arányában az általuk realizált adómegtakarítás legyen

$i_{D_{t}}=\frac{T S C F_{D_{t}}}{D_{t-1}}$.

és

$i_{E_{t}}=\frac{T S C F_{E_{t}}}{E_{t-1}}$.

Innen a WACC társaságiadó-hatással módosított képlete:

$W A C C=\frac{D}{V} r_{D}-\frac{D}{V} i_{D}+\frac{D}{V} y_{D}+\frac{E}{V} r_{E}-\frac{E}{V} i_{E}+\frac{E}{V} y_{E}$.

A társaságiadó-hatással kiegészített számítási példa részleteit a 8. táblázat mutatja. 
8. táblázat

Piaci értékek finanszírozási tranzakciós költségekkel és adóhatásokkal, $k_{D}<r_{D}$

\begin{tabular}{lrrrr}
\hline & $1 . e ́ v$ & 2. év & 3. év & 4 év és utána \\
\hline$V T S$ - és TC-hatás nélkül & 330,77 & 353,84 & 372,77 & 387,50 \\
$T C C F$ & 2,00 & 4,00 & 2,00 & 3,00 \\
$T C$ év elején & 33,98 & 35,38 & 35,27 & 37,50 \\
$T S C F_{D}$ & 0,50 & 0,40 & 0,55 & 0,60 \\
$T S$ CF & 0,10 & 0,20 & 0,15 & 0,12 \\
$T S$ CF & 0,60 & 0,60 & 0,70 & 0,72 \\
$T S$ év elején & 8,13 & 8,34 & 8,66 & 9,00 \\
$V$ TS- és TC-hatással év elején & 304,92 & 326,81 & 346,16 & 359,00 \\
\hline$D$ év elején & 97,26 & 98,15 & 99,06 & 107,70 \\
$E$ év elején & 207,66 & 228,66 & 247,10 & 251,30 \\
\hline$D / V$ TS- és TC-hatással (százalék) & 31,90 & 30,03 & 28,62 & 30,00 \\
$E / V$ TS- és TC-hatással (százalék) & 68,10 & 69,97 & 71,38 & 70,00 \\
$r_{D}$ (százalék) & 4,00 & 5,00 & 6,00 & 6,00 \\
$i_{D}$ (százalék) & 0,51 & 0,41 & 0,56 & 0,56 \\
$y_{D}$ (százalék) & 2,06 & 3,06 & 1,01 & 1,86 \\
$r_{E}$ (százalék) & 12,81 & 13,58 & 14,41 & 16,00 \\
$i_{E}$ (százalék) & 0,05 & 0,09 & 0,06 & 0,05 \\
$y_{E}$ (százalék) & 0,00 & 0,44 & 0,40 & 0,40 \\
$W A C C$ (százalék) & 10,46 & 12,04 & 12,38 & 13,64 \\
\hline
\end{tabular}

\section{A klasszikus WACC formula feltevései}

A (18) képlet első látásra nem feltétlenül ismerős. Tekintsük át, milyen feltevések kellenek ahhoz, hogy a különféle vállalati pénzügyi könyvek klasszikus képletváltozatához jussunk!

1. Az első feltevésünk az, hogy nincsenek tranzakciós költségek, vagyis $y_{D}=y_{E}=y_{V}=0 . \mathrm{Ez}$ a (19) képlethez vezet. A gyakorlatban ezt könnyen cáfolhatjuk, például a különféle hitelekhez kapcsolódó banki információszolgáltatás cégen belül felmerülő többletköltségeivel.

$W A C C=\frac{D}{V} r_{D}-\frac{D}{V} i_{D}+\frac{E}{V} r_{E}-\frac{E}{V} i_{E}$.

2. A második kitétel szerint a saját tőke finanszírozásához nem kapcsolódik adópajzshatás. Ehhez az szükséges, hogy a tulajdonosok a vállalkozás jövedelméböl kizárólag osztalékágon vagy részvény-visszavásárlás révén részesedjenek, semmilyen magánkiadásukat ne terheljék a vállalatra. Így jutunk a (20) képlethez. 
$W A C C=\frac{D}{V} r_{D}-\frac{D}{V} i_{D}+\frac{E}{V} r_{E}$.

3. A harmadik feltevés az, hogy a hitelek okozta adómegtakarítás nagyságát a kamatfizetés és az effektív adó szorzataként számszerüsíthetjük. Nincsen tehát például számlavezetési díj, rendelkezésre tartási jutalék, hitelbírálati díj, a hitelezők kizárólag kamatjövedelemhez jutnak a cégtől. Nincsen különféle hitelek után speciális adókedvezmény sem. Ezt a változatot a (21) képlet tükrözi.

$W A C C=\frac{D}{V} r_{D}-\frac{\text { kamatfizetés } \times t}{V}+\frac{E}{V} r_{E}$.

4. Az utolsó feltevésünk szerint a hitelek piaci értékének $(D)$ és elvárt hozamának $\left(r_{D}\right)$ szorzata pontosan megegyezik az adóalapot csökkentő kamatfizetéssel. Ez azt jelenti, hogy a hitelezők kizárólag kamatjövedelemként realizálják az elvárt hozamot, tehát nincsen árfolyamnyereségük vagy -veszteségük, vagyis a hitelek piaci és könyv szerinti (név-) értéke a teljes futamidő alatt azonos. Így jutunk a legtöbb közgazdász által fejből is ismert (22) képlethez.

$W A C C=\frac{D}{V} r_{D}-\frac{D \times r_{D} \times t}{V}+\frac{E}{V} r_{E}=\frac{D}{V}\left(r_{D}-r_{D} \times t\right)+\frac{E}{V} r_{E}=\frac{D}{V} r_{D}(1-t)+\frac{E}{V} r_{E}$.

\section{Következtetések}

A súlyozott átlagos tőkeköltséget igen széles körben alkalmazzák a napi gyakorlatban a vállalati pénzügyek területén dolgozók. Számos részvényértékelés, beruházási döntés épül a kizárólag a működés és a befektetések pénzáramláshatásait tartalmazó vállalati szabad cash flow (FCFF) WACC-vel való diszkontálására. Ugyanakkor a legtöbben nincsenek tudatában annak, hogy a WACC képletének közismert, igencsak leegyszerüsített változatát csak akkor alkalmazhatjuk, ha joggal feltételezhetjük a következőket.

1. Nincsenek a finanszírozással kapcsolatos tranzakciós költségek, amelyeket a vállalatnak kell megfizetnie, de nem a finanszírozók kapják, vagy azokra a szokásos elvárt hozamon felül, például kapcsolódó költségeik megtérítéseként tartanak igényt.

2. A saját töke finanszírozásához kapcsolódóan semmiféle adópajzshatás sem realizálható. Nincsenek tehát olyan, tulajdonosi hozamba beleszámító vagyonkivétek (vállalati ráfordítások), amelyek a cég számviteli eredményét csökkentik.

3. A hitelekhez kapcsolódó adópajzshatást pontosan becsülhetjük a kamatok és az effektív adókulcs szorzataként. Nincsenek különféle hitelekhez kapcsolódó adókedvezmények, és minimális elvárt adó sincs, amely olyankor is pozitív effektív adókulcsot eredményezne, amikor adópajzs nem érvényesíthető.

4. A hitelekhez köthetö kamatfizetést jól becsüli a hitelek piaci értékének és elvárt hozamának szorzata. Nincsenek tehát a hitelezőknek fizetendő egyéb, a hozamukba beletartozó díjak, és nem realizálnak árfolyamnyereséget vagy -veszteséget sem, tehát a hitelek piaci és könyv szerinti értéke a teljes előrejelzési időtartamra megegyezik. 
Ha e feltevések nem reálisak, helyesebb lehet, ha a WACC kiterjesztett változatának alkalmazásához folyamodunk, amelynek egyik lehetséges felírási változatát a (23) képlet mutatja.

$W A C C=\frac{D}{V} r_{D}-\frac{D}{V} i_{D}+\frac{D}{V} y_{D}+\frac{E}{V} r_{E}-\frac{E}{V} i_{E}+\frac{E}{V} y_{E}$.

Itt a $D$ a hitelek értékét, az $E$ a saját tőke értékét, a $V$ pedig a vállalat piaci értékét jelenti egy adott időszak kezdetén, s mindig teljesül a $V=D+E$ összefüggés. Az $r_{D}$ a hitelek, $\mathrm{az} r_{E}$ a saját tőke elvárt hozama az adott időszakban, míg $i$ az adott időszakban elérhető adómegtakarítás pénzáramlása, és az időszak eleji $D$ - vagy $E$-érték viszonyát mutatja. Ugyanakkor $y$ a kétféle finanszírozási forráshoz köthető időszaki tranzakciós költségek termelte pénzáramlás és a megfelelő finanszírozási forrás időszak eleji értékének hányadosa. Ha $i$ vagy $y D$-re és $E$-re is azonos, az adott tétel indexelhető $V$-vel, és súlyozás helyett pusztán hozzáadhatjuk az operatív tőkeköltséghez $\left(r_{A}\right)$.

A helyzetet bonyolítja, hogy a finanszírozás egyes tranzakciós költségei adópajzshatással is járhatnak. A bemutatott számításoknál a finanszírozási adópajzs már tartalmazta nemcsak a kamatfizetés, de a finanszírozás tranzakciós költségei miatt jelentkező adópajzshatást is.

A WACC kiterjesztett képlete nem azt jelenti, hogy a különféle tranzakciós és adóhatásoknak együtt kell mozogniuk a $D$, az $E$ vagy a $V$ valamelyikével. (Az $i$ és $y$ értékei az egyes időszakokban szabadon változhatnak.) Sokkal inkább arról van szó, hogy csak abban az esetben használjuk a WACC meghatározását igénylő FCFF megközelítést az adott értékelési problémánál, ha ezen arányok minden egyes érintett időszakra ismertek. Ha a kellő információ nem áll rendelkezésre, az APV módszert használhatjuk, amely mindig pontosan ugyanazon eredményre vezet, mint az FCFF (vállalati szabad pénzáramlást használó) szemlélet. Amennyiben a megfelelő pénzáramlások nominálisan ismertek, alkalmazható ugyan az FCFF megközelítés, azonban többszörös iterációkra lehet szükség ahhoz, hogy számszerüsítsük azt a $V$ meghatározásához szükséges WACC-tőkeköltséget, amelynek pontos kiszámításához ismerni kellene a $V$ értékét.

Emiatt a WACC tankönyvekből ismert hagyományos, erősen leegyszerűsített képletének alkalmazásakor tanácsos a megszokottnál jóval óvatosabban eljárni. Érdemes megfontolni azt is, hogy a most bemutatott általánosított WACC-képlet oktatása legalább a pénzügy szakos hallgatók egyetemi képzésébe bekerüljön.

\section{Hivatkozások}

Adamczy к, P.-Zbroszczyк, A. [2017a]: Business Valuation. Practice of domestic WSE members in 2016. Zeszyty Naukowe Uniwersytetu Szczecińskiego. Finanse Rynki Finansowe Ubezpieczenia, Vol. 89. No. 2. 233-249 o. https://doi.org/10.18276/frfu.2017.89/2-17.

Adamczy K, P.-Zbroszczy , A. [2017b]: A Key Factor of the DCF Model Coherency. Journal of Economics and Management, Vol. 28. No. 2. 5-22. o. https://doi.org/10.22367/ jem.2017.28.01. 
Ansay, T. [2009]: Firm Valuation: Tax Shields \& Discount Rates. MPRA Paper, No. 23027. University Library of Munich, Germany. https://ideas.repec.org/p/pra/mprapa/23027.html. Block, S. [2011]: Does the Weighted Average Cost of Capital Describe the Real-World Approach to the Discount Rate? The Engineering Economist, Vol. 56. No. 2. 170-180. o. https://doi.org/10.1080/0013791x.2011.573618.

Brusov, P.-Filatova, T.-Orehova, N.-Brusova, N. [2011]: Weighted Average Cost of Capital in the Theory of Modigliani-Miller. Modified for a Finite Lifetime Company. Applied Financial Economics, Vol. 21. No. 11. 815-824. o. https://doi.org/10.1080/0960 3107.2010.537635.

DeMarzo, P. M. [2005]: Discounting Tax Shields and the Unlevered Cost of Capital. December 12. http://dx.doi.org/10.2139/ssrn.1488437.

Dempsey, M. [2013]: Consistent Cash Flow Valuation with Tax-Deductible Debt: A Clarification. European Financial Management, Vol. 19. No. 4. 830-836. o. https://doi.org/10.1111/ j.1468-036X.2011.00625.x.

Easton, P. D.-Sommers, G. A. [2017]: Two Different Ways of Treating Corporate Cash in FCF Valuations-and the Importance of Getting the Cost of Capital Right. Journal of Applied Corporate Finance, Vol. 29. No. 3. 71-79. o. https://doi.org/10.1111/jacf.12251.

Kolari, J. W. [2014]: Discounting Debt Tax Shields at the Levered Cost of Equity. https:// www.researchgate.net/publication/228917592_Discounting_Debt_Tax_Shields_at_the_ Levered_Cost_of_Equity.

Koller, T.-Goedhart, M.-Wessels, D. [2010]: Valuation: Measuring and Managing the Value of Companies. JohnWiley \& Sons, 5th Edition, Hoboken, New Jersey.

Miller, M. H.-Modigliani, M. [1961]: Dividend Policy, Growth, and the Valuation of Shares. Journal of Business, Vol. 34. No. 4. 411-433. o. https://doi.org/10.1086/294442.

Qi, H.-Liu, S.-Johnson, D. [2012]: A Model for Risky Cash Flows and Tax Shields. Journal of Economics \& Finance, Vol. 36. No. 4. 868-881. o. http://dx.doi.org/10.1007/s12197010-9162-7.

Vélez-Pareja, I.-Burbano-Pérez, A. [2005]: A Practical Guide for Consistency in Valuation: Cash Flows, Terminal Value and Cost of Capital. Economic Analysis Working Papers, Vol. 5. No. 7. http://www.unagaliciamoderna.com/eawp/coldata/upload/A\%20practical\% 20guide\%20for\%20consistency\%20in\%20valuation.pdf.

Vélez-Pareja, I.-Tham, J. [2005]: Market Value Calculation and the Solution of Circularity Between Value and the Weighted Average Cost of Capital WACC (A Note on the Weighted Average Cost of Capital WACC). Revista de Administração Mackenzie (RAM), Vol. 10. No. 6. http://dx.doi.org/10.2139/ssrn.254587. 